\title{
Scientific Investigations of a 16th Century Stall Belonging to the Evangelic Church in Bistrița, Bistrița-Năsăud County, Romania
}

\author{
C. Marutoiu, ${ }^{1}$ S. P. Grapini, ${ }^{1}$ A. Baciu, ${ }^{1}$ M. Miclaus, ${ }^{2}$ \\ V. C. Marutoiu, ${ }^{1}$ S. Dreve, ${ }^{2}$ I. Kacso, ${ }^{2}$ and I. Bratu ${ }^{2}$ \\ ${ }^{1}$ Faculty of Orthodox Theology, Babeş-Bolyai University Cluj-Napoca, 18 Avram Iancu Square, 40017 Cluj-Napoca, Romania \\ ${ }^{2}$ National Institute for Research and Development of Isotopic and Molecular Technologies, 65-103 Donáth, \\ 400293 Cluj-Napoca, Romania
}

Correspondence should be addressed to I. Bratu; ibratu@gmail.com

Received 28 June 2012; Revised 27 November 2012; Accepted 3 December 2012

Academic Editor: Dhananjay Bodas

Copyright (C) 2013 C. Marutoiu et al. This is an open access article distributed under the Creative Commons Attribution License, which permits unrestricted use, distribution, and reproduction in any medium, provided the original work is properly cited.

\begin{abstract}
The Evangelic Church in Bistrița city is one of the important gothic monuments in Romania. Inside the church there have been preserved a series of furniture pieces from different centuries, and the stall that has been analysed in this study is one of them. The study presents the investigations that were made on the occasion of restoring the stall. The nature and the status of the wooden supports and also the composition of the painting layer which covers the front side of the stall were investigated by several methods: Fourier transform infrared (FTIR) spectroscopy, X-ray diffraction (XRD), and differential scanning calorimetry (DSC) analyses. The back side of the stall was made of spruce fir wood and its status was also investigated. The nature of the component elements and the heritage value of the ensemble were also established.
\end{abstract}

\section{Introduction}

Located at the foot of the Bârgău Mountains, not far from the Bârgău Pass (Pasul Tihuța in Romanian) which connects Transylvania region to the Bucovina one, the town of Bistrița is one of the oldest around. The greatest attraction of Bistrița is the Evangelical Church (see Figure 1) built by Transylvanian Saxons centuries ago.

The first mentioned parish in official documents was Johannis plebanus de Bystricia, noted in the papal tax registers of 1332-1333. The construction of the Gothic church with Renaissance elements (i.e., the pews) began in 1470 and was completed almost 100 years later by Petrus Italus de Lugano, who added renaissance elements to the structure.

The furniture was made at the beginning of the XVI century and it is the object of an exquisite craftsmanship. The two stalls, sculpted and decorated with marquetry details, as well as a seats' bench that has a gothic inscription and Early Renaissance ornaments-piece made in 1516 by the monk Benedict of Beclean-were brought from the Dominican Monastery after its ruining during the Reform time. The bench of the hospital magister was the work of a craftsman named Anton, in 1508, and it was decorated in a manner that it can be found in Late Gothic geometry. Another valuable piece is the sacristy's cabinet, dated, as the inscription says, from 1507. The door of the sacristy carries a true artistic value (with marquetry details, dated 1563) and the stall placed in the right side of the door-dated in back to 1564 . Those pieces are added to many other dated back to the XVII and XVIII century, decorated with painted ornaments, inscriptions, and guild marks [1-3]. The analysis of the wood artifacts can be made through optical microscopy [4], microtomography with synchrotron radiations [5], and the identification of wood species by SEM [6]. Unfortunately, in 2008 a fire ruined the steeple. The restoration works started in 2010.

The aim of this paper was to identify the employed materials (wood and pigments) in the Bistrița Evangelic Church wooden stall. Because pigments based on copper carbonates exclude some procedures usually applied on painted surfaces, it becomes important to identify the nature of the pigments present in the painting covering the front side of the stall. 


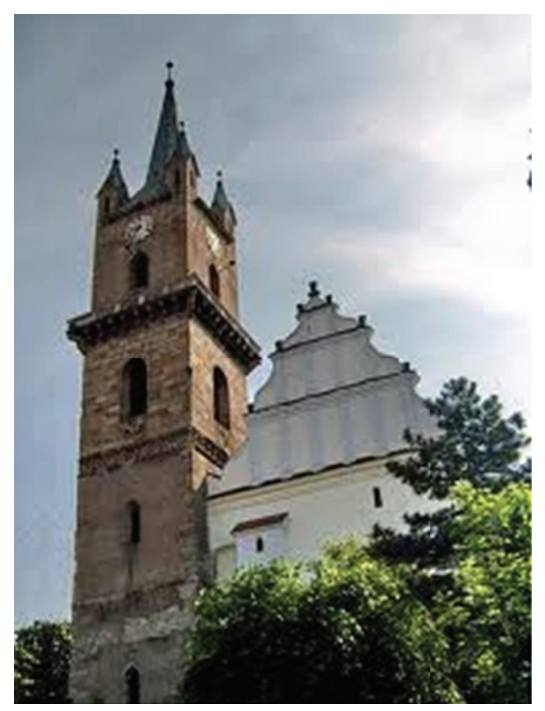

FIgure 1: Bistrița’s Evangelical Church.

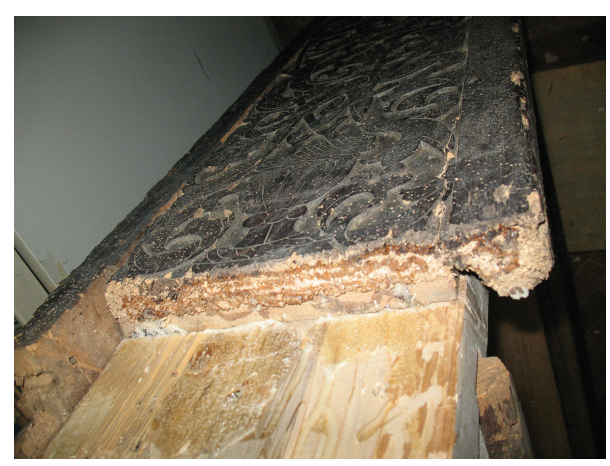

FIgURE 2: The place where wood samples were taken.

\section{Materials and Methods}

The lime and spruce fir wooden samples (collected from the wooden stall; see Figure 2 and recent ones collected from icon painting supports) were investigated with FTIR (JASCO 6100 in the $4000-400 \mathrm{~cm}^{-1}$ spectral domain with a resolution of $4 \mathrm{~cm}^{-1}$ using $\mathrm{KBr}$ pellet technique) and fluorescence (ABLE \& JASCO FP 6500, 200-900 nm spectral domain and usual solid sample setup) spectrometers, DSC (DSC-60 Shimadzu calorimeter in the $20-550^{\circ} \mathrm{C}$ temperature range, with heating rate of $10^{\circ} \mathrm{C} / \mathrm{min}$ in crimped aluminum sample cell, under nitrogen flow of $60 \mathrm{~mL} / \mathrm{min}$ ), and X-ray diffraction (Bruker D8 AVANCE) techniques. The pigments' collected samples (Figures 3 and 4) were analysed by FTIR spectroscopy using $\mathrm{KBr}$ pellet technique, as well. The diffraction data were collected in the $2 \theta=3-85^{\circ}$ angular domain with a Bruker D8 Advance diffractometer, using $\mathrm{Cu} \mathrm{K} \alpha$ radiation $(\lambda=1.5406 \AA)(40 \mathrm{kV} ; 40 \mathrm{~mA})$. In order to increase the resolution, a Ge 111 monochromator was used to eliminate the $\mathrm{K} \alpha 2$ radiation. Data collection was performed at room temperature with the programs package DIFFRAC plus XRD

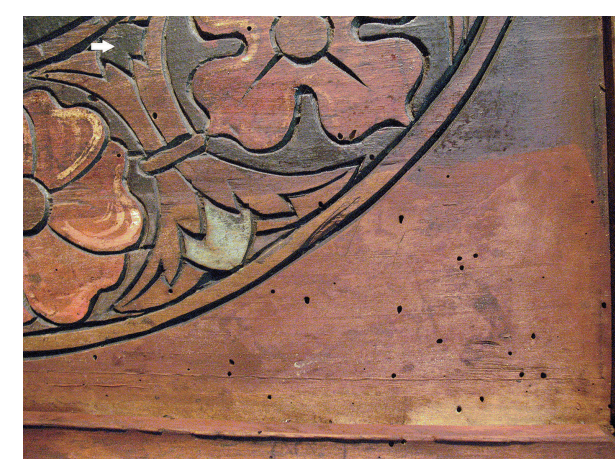

FIgURE 3: The place where a green sample was taken.

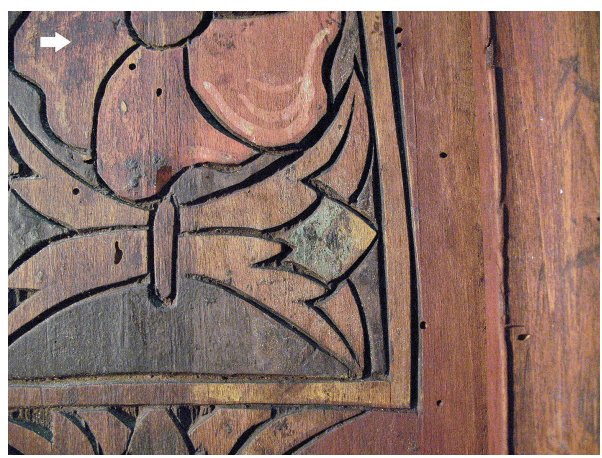

Figure 4: The place where a reddish-brown sample was taken.

TABLE 1: Crystallinity status Cr.I for stall lime (internally and externally degraded) and new lime woods.

\begin{tabular}{lcc}
\hline & $A_{1106} / A_{690}$ & \\
lime externally degraded & Lime internally degraded & Lime new \\
\hline 2.63 & 2.17 & 2.93 \\
\hline
\end{tabular}

Commander. The amorphous/crystalline ratio was calculated by using Material Studio software.

\section{Results and Discussion}

3.1. FTIR Spectroscopy. Two types of wood-lime (front side of the stall) and spruce fir (back side of the stall)-were sampled, cleaned, grinded, and analysed.

FTIR investigation and comparison between stall wood and new wood samples is presented in Figures 5 and 6 .

The crystallinity index (Cr.I) was determined as was defined before [7], by taking into account the corresponding absorption band intensities ratio. The results are presented in Table 1.

Lignin-to-cellulose $(\mathrm{L} / \mathrm{C})$ ratio was determined taking into account several definitions [7] for lignin and cellulose characteristic band intensities, respectively. The results are presented in Table 2.

As the result of the analysis of these spectra, several characteristics of these wooden samples were obtained. 


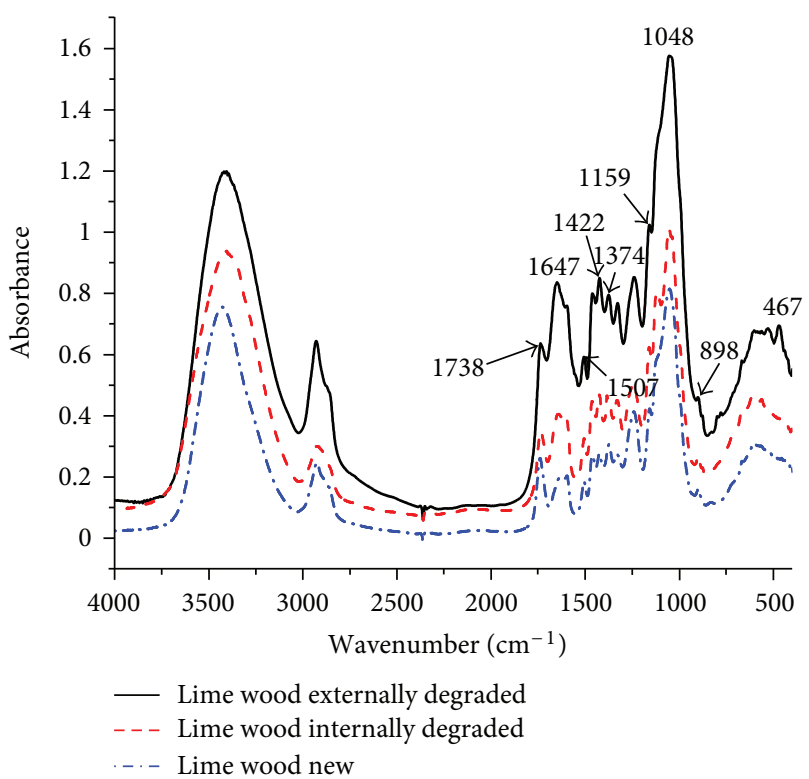

FIGURE 5: FTIR spectra of the stall and new lime wood samples.

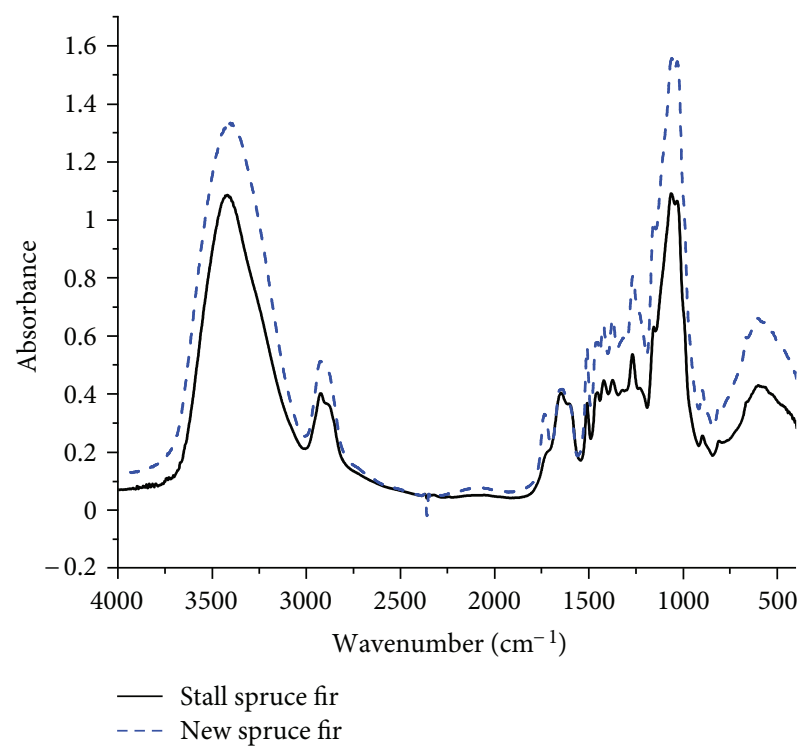

FIGURE 6: FTIR spectra of the stall and new spruce fir wood samples.

(1) The crystallinity degree of the wooden samples is lower for the historical woods as compared to the recent ones; probably for the historical wood the cellulose becomes more amorphous than that for the modern wood.

(2) The lignin/cellulose ratio is higher for historical woods as compared to the recent ones.

The degradation of wooden cellulose is more pronounced (the carbohydrates are firstly degraded by microorganisms) than that for wooden lignin (more slowly degraded) and is independently of the nature of the wood [7].
TABLE 2: Lignin-to-cellulose (L/C) ratios taking into account their different specific bands.

\begin{tabular}{lcc}
\hline Lime ext. & Lime int. & Lime new \\
\hline \multicolumn{3}{c}{$A_{1505} / A_{1738}$} \\
0.93 & 0.95 & 0.72 \\
\hline \multicolumn{3}{c}{$A_{1505} / A_{1375}$} \\
0.71 & 0.57 \\
0.58 & $A_{1505} / A_{1158}$ \\
1.28 & 0.54 & 0.44 \\
\hline
\end{tabular}

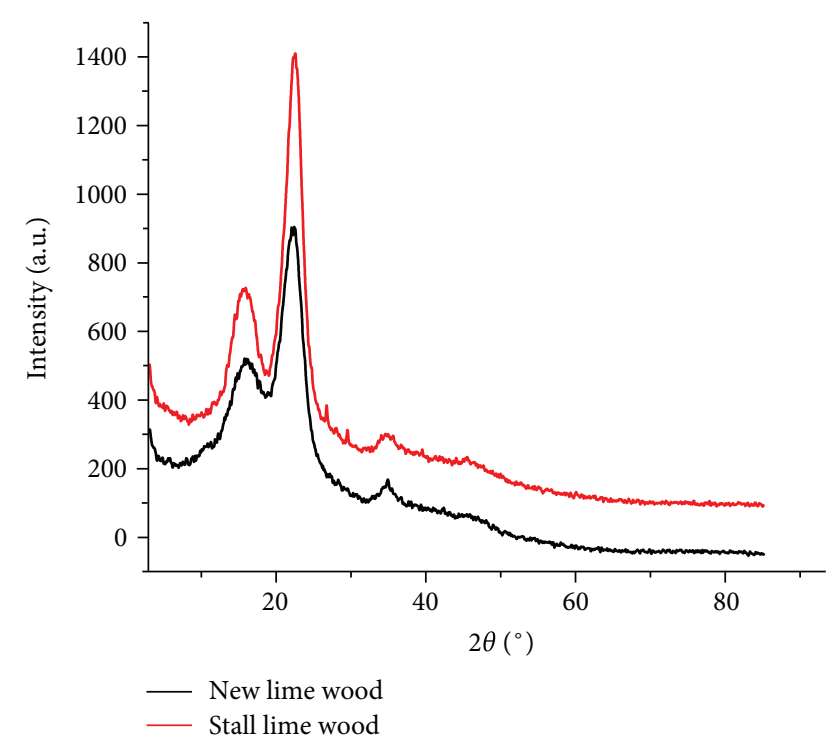

FIGURE 7: XRD patterns of the new lime wood and of the stall lime wood.

3.2. X-Ray Diffraction. Both crystalline and amorphous phases are present in the samples. The X-ray procedure for the crystallinity degree estimation is based upon measurement of the total X-ray scattering and of the crystalline phase. It was established that the crystallinity degree is lower for a historical wood as compared to the actual one. Also, the diffraction peak of the historical wood is shifted towards higher angle values, which means that the lattice constants are lower as compared to the actual wood's values.

The diffraction peaks shifted to higher angles for both stall wood essences being compared with that of the new wood. This means that the elementary cell is diminished in time that can be explained by the fact that some of wood components, the volatile components are being diminished.

We have obtained $52.37 \%$ crystallinity for new lime wood compared to $49.61 \%$ crystallinity degree for stall lime wood.

It was established that the crystallinity degree is lower for a historical spruce fir wood as compared to the actual one (Figures 7 and 8). Also, the diffraction peak of the historical wood is shifted towards higher angle values which mean that the lattice constants are lower as compared to the actual spruce fir wood's values. The historical spruce fir wood is 


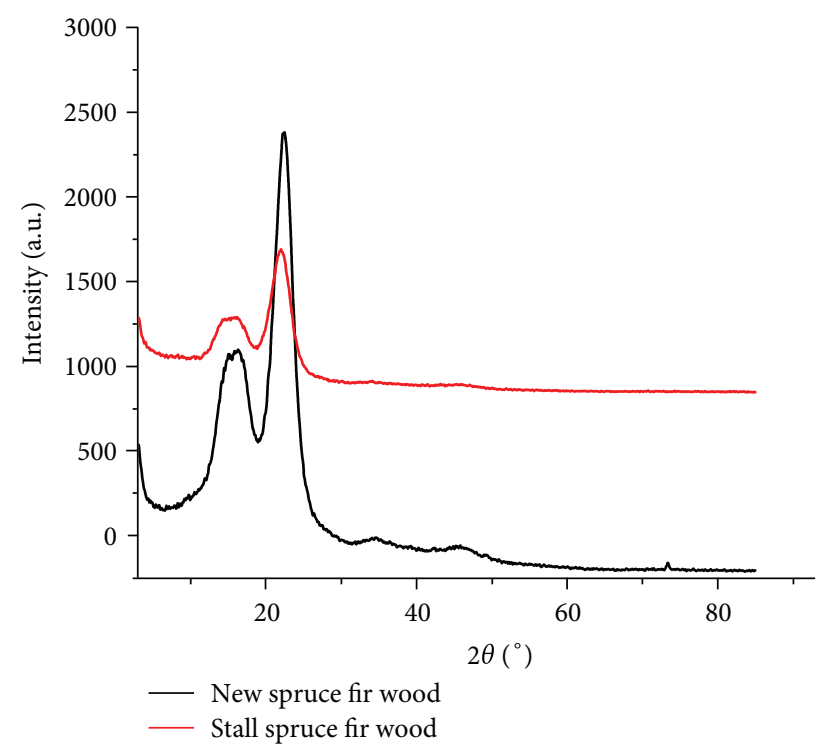

FIGURE 8: XRD patterns of the new spruce fir wood and of the stall spruce fir wood.

more compact than the actual one. We have obtained also $48.54 \%$ crystallinity for new spruce fir wood compared with $46.75 \%$ crystallinity degree for stall spruce fir wood.

3.3. DSC. The spruce fire wood sample presents two exothermic signals in DSC curve (Figure 9), between 290 and $390^{\circ} \mathrm{C}$ (peak maxima at $345^{\circ} \mathrm{C}$ ) and between 435 and $90^{\circ} \mathrm{C}$ (peak maximum at $473^{\circ} \mathrm{C}$ ), assigned to cellulose, respectively, to the native lignin decomposition [8].The DSC curve of the stall spruce fir wood presents a shoulder around $300^{\circ} \mathrm{C}$, an additional peak around $400^{\circ} \mathrm{C}$, a broad cellulose peak shifted to $324^{\circ} \mathrm{C}$, and a strong sharp peak with maximum at $463^{\circ} \mathrm{C}$. The enlargement of the cellulose peak occurs due to the crystalline/amorphous transformation of the wood during the time, and the maximum is shifted due to the material degrading [9].

The strong peak at $463^{\circ} \mathrm{C}$ is probably due to the presence of oxalates, as a result of the wood-boring beetle and fungal attack.

3.4. Fluorescence Spectroscopy. Cellulose expresses its fluorescence in the $440-468 \mathrm{~nm}$ characteristic region for both old and new spruce fir wood and for lime samples, respectively, while lignin presents a much lower fluorescence for all samples, at an excitation of $375 \mathrm{~nm}$ (Figure 10).

The phenomenon is generated by the equally graduated degradation of wooden cellulose independently of the nature of the wood. The fluorescence is increasing with the period of degradation being specifically expressed for each kind of tested wood samples [10]. In the same time, fluorescence of new spruce fir samples is more intense than the old spruce fir samples, a phenomenon that can be attributed to the presence of aromatic fluorescent volatile compounds in new wood sample, which decompose in time and do not appear in the old (stall) spruce fir sample.

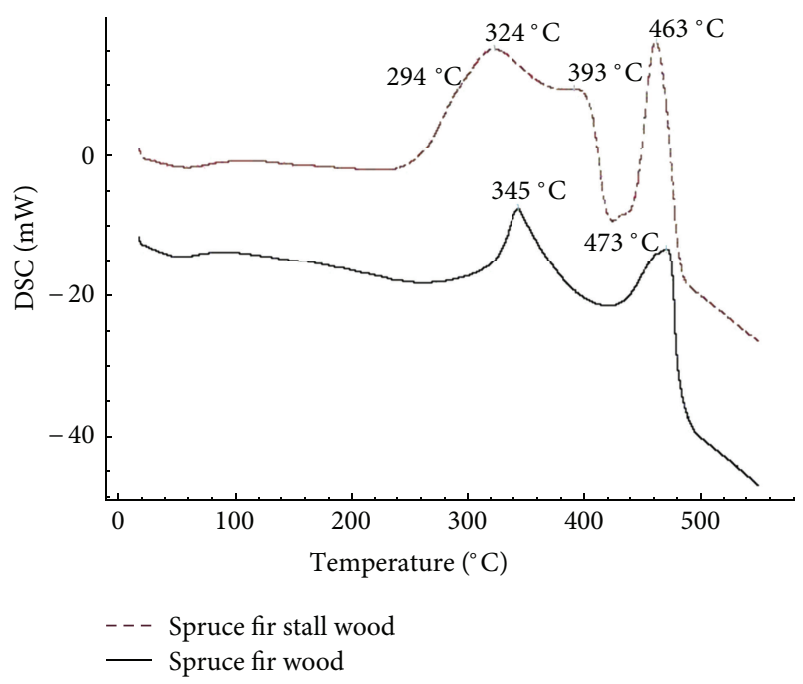

FIGURE 9: DSC curves for spruce fir wood: solid line (etalon); dash line (stall wood sample).

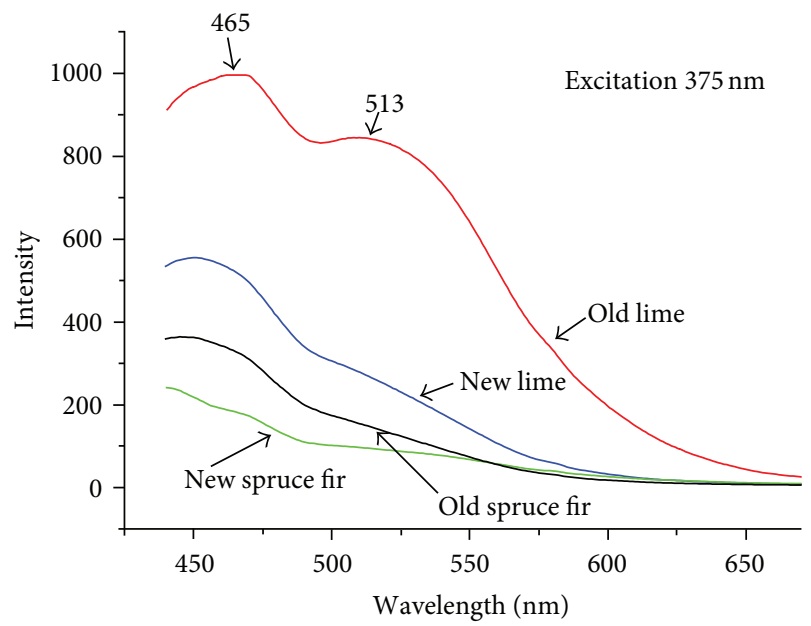

FIGURE 10: Fluorescence spectra of new lime wood (blue), old (stall) lime wood (red), new spruce fir wood (black), and old (stall) spruce fir wood (green), respectively, for an excitation at $375 \mathrm{~nm}$.

3.5. Pigment Analysis. For the identification of the green pigment, it was produced in the laboratory a green color sample by mixing malachite and animal glue binder [11]. The resulting spectra are presented in Figure 11.

Figure 12 presents the spectra of the standard pigments and of the brown pigment used for wooden stall painting: brown pigment $-\mathrm{Fe}_{2} \mathrm{O}_{3}$.

Consequently, the pigments used in stall wood painting were identified as follows:

(i) green-malachite,

(ii) reddish brown $-\mathrm{Fe}_{2} \mathrm{O}_{3}$.

The binder was identified as animal glue. 


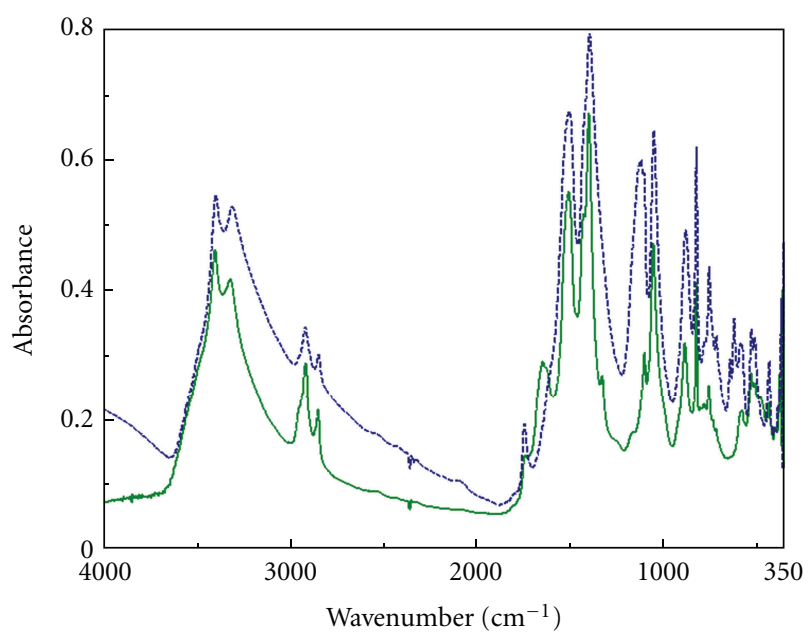

FIGURE 11: FTIR spectra of the green pigment sample: solid line (stall wood); dash line (malachite + binder).

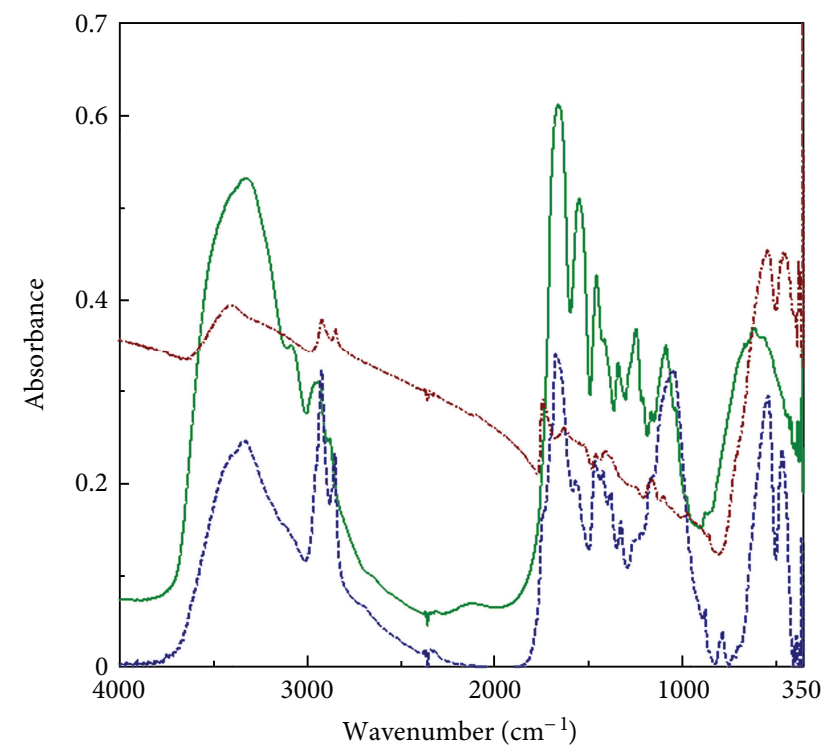

FIGURE 12: FTIR spectra of the dark red sample: solid line (animal glue); dash line (brown pigment + binder); dash-dot line $\left(\mathrm{Fe}_{2} \mathrm{O}_{3}+\right.$ binder $)$.

\section{Conclusions}

The employed techniques demonstrated the nature and the preservation state of the materials used for the Evangelic Church stall in Bistrița.

The lime and spruce fir wood essences used for the front and back sides of the church stall present two characteristics:

(i) their crystallinity decreases as compared to a modern wood sample;

(ii) the fungal attack was identified especially for the spruce fir wood;

(iii) fluorescence parameters depending of specificity and age of wooden samples can contribute for the artifacts' identification through lignin and volatile aromatic compounds, while cellulose decomposes equally independently of the wood nature;

(iv) the painting materials used for wooden stall were identified as binder (animal glue), reddish brown (iron oxide) and green (malachite).

\section{Acknowledgment}

This paper was presented in part at $\mathrm{CMA} 4 \mathrm{CH}$ 2012, Rome, Italy, 27-30 May 2012.

\section{References}

[1] V. Drăguț, Gothic Art in Transylvania, Meridiane Publishing House, Bucharest, Romania, 1979.

[2] V. Drăguț, Medieval Art Encyclopedic Dictionary, Scientific Publishing House, Bucharest, Romania, 1976.

[3] V. Vătăşianu, Feudal Art History in Romanian Countries, The Academy of Romanian P.R. Publishing House, Bucharest, Romania, 1959.

[4] M. C. Timar, L. Gurău, and M. Porojan, "Wood species identification, a challenge of scientific conservation," International Journal of Conservation Science, vol. 3, pp. 11-22, 2012.

[5] S. Mizuno, R. Torizu, and J. Sugiyama, "Wood identification of a wooden mask using synchrotron X-ray microtomography," Journal of Archaeological Science, vol. 37, no. 11, pp. 2842-2845, 2010.

[6] N. Macchioni and S. Lazzeri, "Lidentificazione delle specie legnose e la loro caratterizzazione tecnologica," in Statue di Legno, Caratteristiche Tecnologiche e Formali delle Specie Legnose, G. B. Fidanza and N. Macchioni, Eds., pp. 9-31, Istituto Poligrafico e Zecca dello Stato, Rome, Italy, 2008.

[7] C. M. Popescu, Y. Sakata, M. C. Popescu, A. Osaka, and C. Vasile, "Degradation of lime wood painting supports," $e$ PreservationScience, vol. 2, pp. 19-29, 2005.

[8] U. Reh, G. Kraepelin, and I. Lamprecht, "Use of differential scanning calorimetry for structural analysis of fungally degraded wood," Applied and Environmental Microbiology, vol. 52, no. 5, pp. 1101-1106, 1986.

[9] I. C. A. Sandu, M. Brebu, C. Luca, I. Sandu, and C. Vasile, "Thermogravimetric study on the ageing of lime wood supports of old paintings," Polymer Degradation and Stability, vol. 80, no. 1, pp. 83-91, 2003.

[10] C. Clementi, C. Miliani, A. Romani, and G. Favaro, "In situ fluorimetry: a powerful non-invasive diagnostic technique for natural dyes used in artefacts. Part I. Spectral characterization of orcein in solution, on silk and wool laboratory-standards and a fragment of Renaissance tapestry," Spectrochimica Acta A, vol. 64, no. 4, pp. 906-912, 2006.

[11] A. Baciu, Z. Moldovan, I. Bratu et al., "Comparative study of the painting materials of a series of orthodox icons on wooden and glass support from Transylvania," Current Analytical Chemistry, vol. 6, no. 1, pp. 53-59, 2010. 

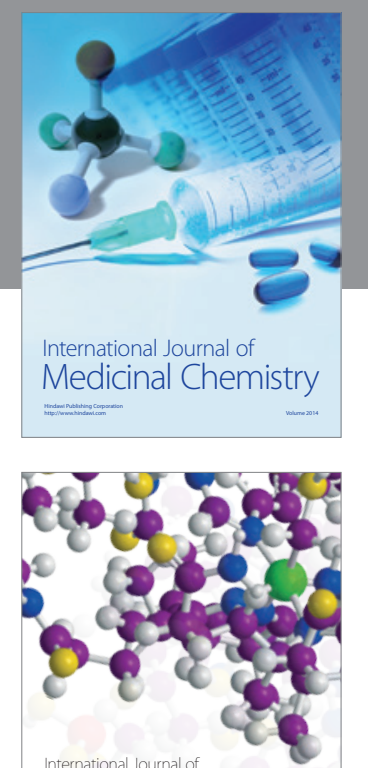

\section{Carbohydrate} Chemistry

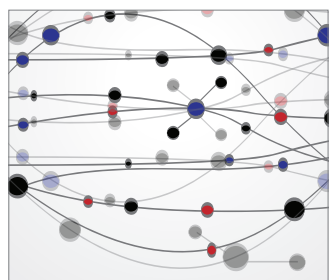

The Scientific World Journal
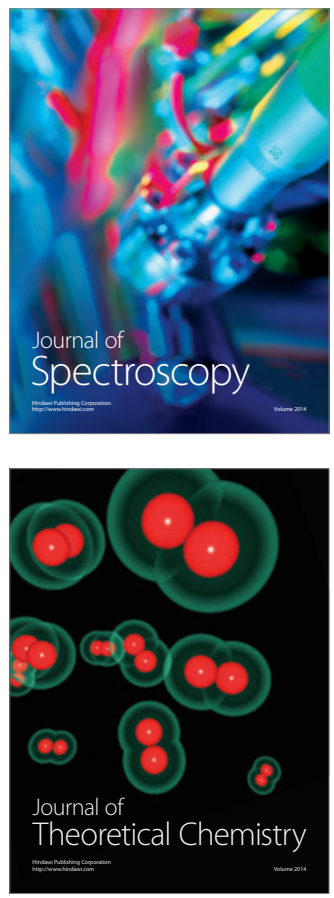
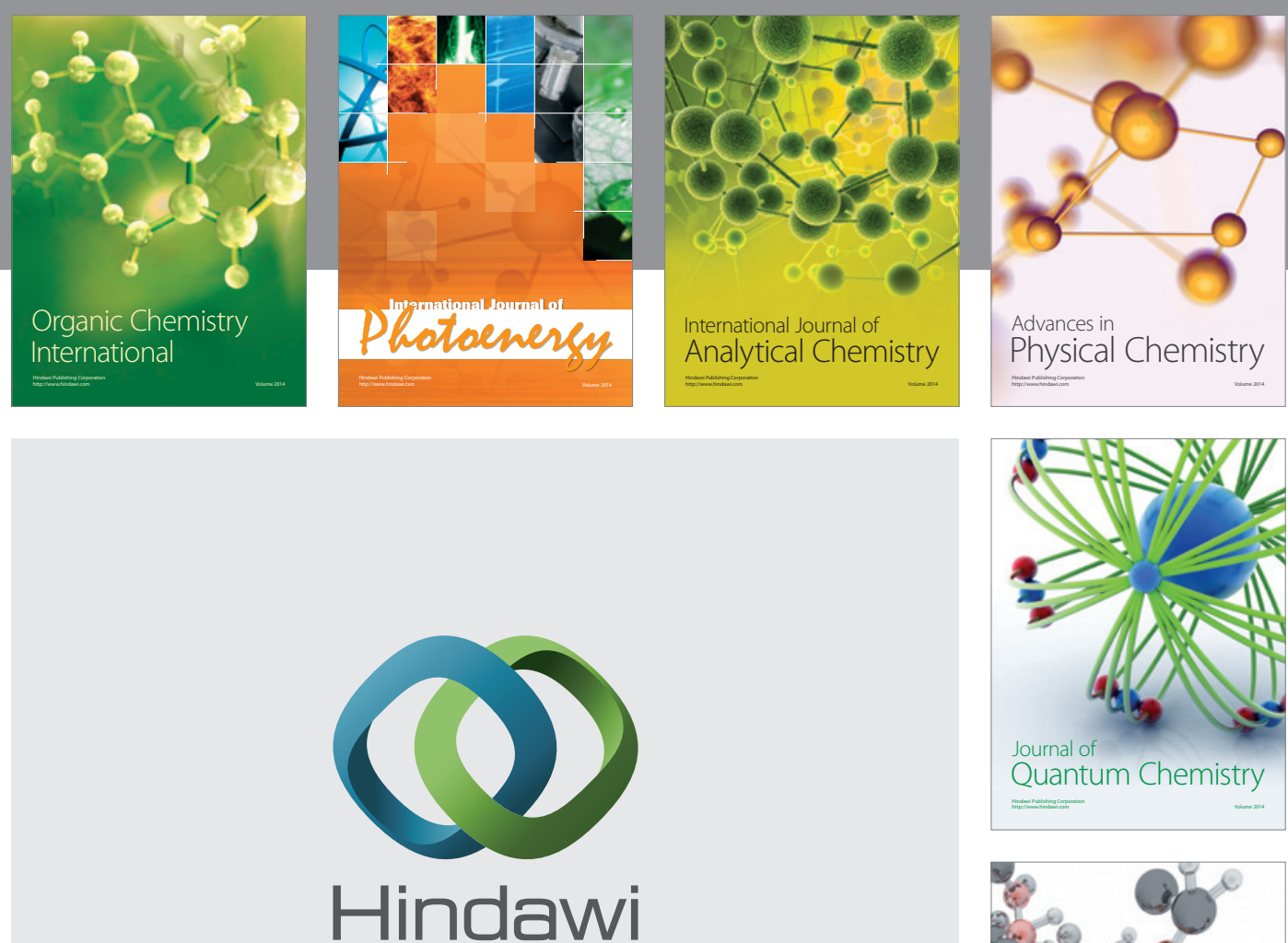

Submit your manuscripts at

http://www.hindawi.com

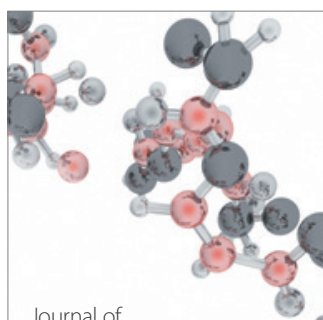

Analytical Methods

in Chemistry

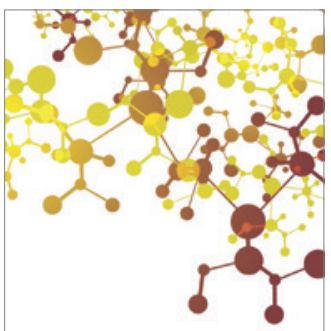

Journal of

Applied Chemistry

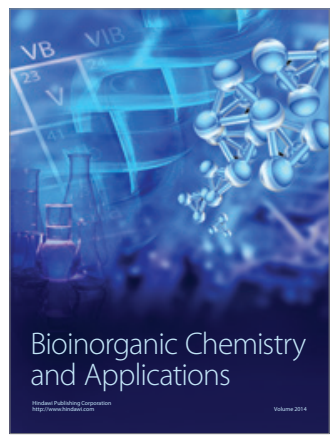

Inorganic Chemistry
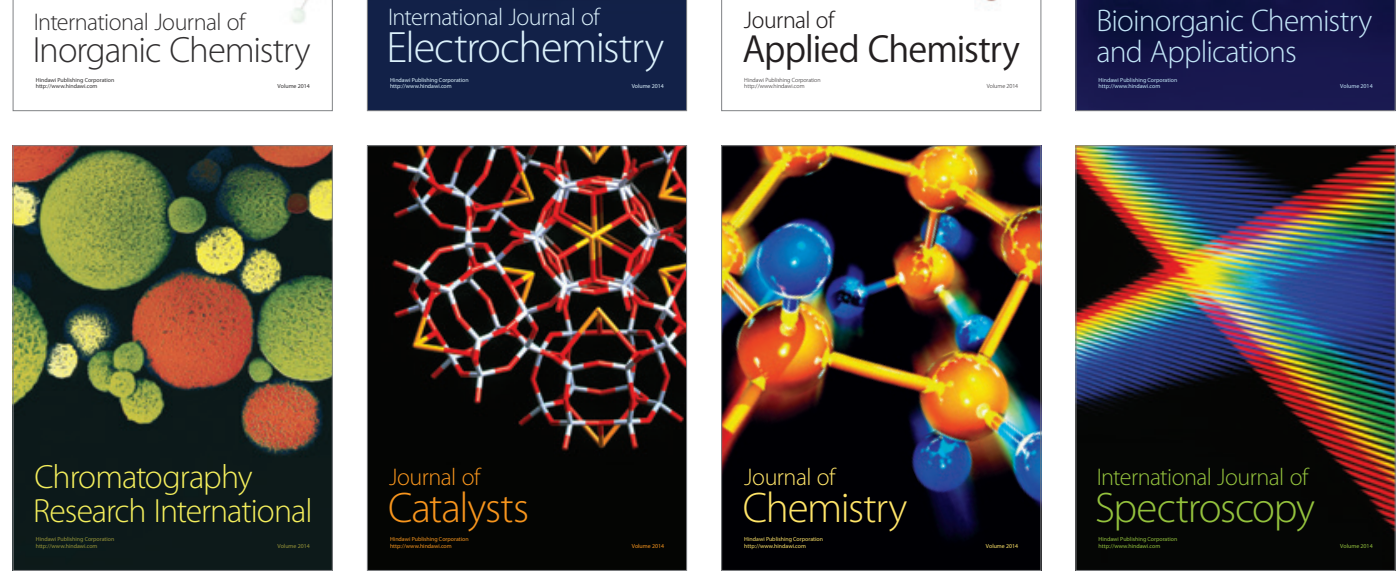